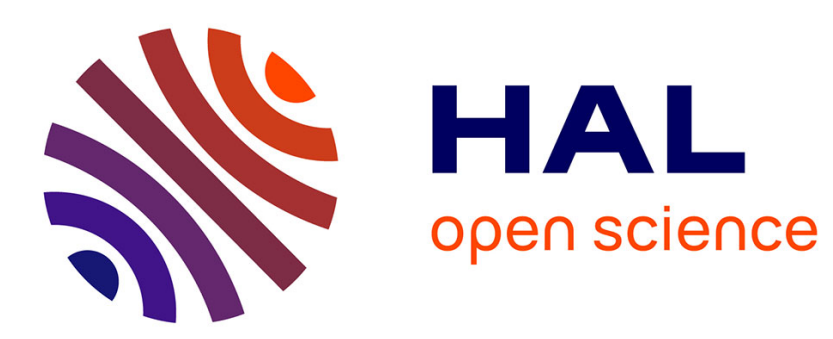

\title{
Fixing Transnational Drug Policy Drug Prohibition in the Eyes of Comparative Law
}

Renaud Colson

\section{To cite this version:}

Renaud Colson. Fixing Transnational Drug Policy Drug Prohibition in the Eyes of Comparative Law. Journal of Law and Society, 2019, 46 (S1), 10.1111/jols.12184 . halshs-02957184

\section{HAL Id: halshs-02957184 \\ https://shs.hal.science/halshs-02957184}

Submitted on 4 Oct 2020

HAL is a multi-disciplinary open access archive for the deposit and dissemination of scientific research documents, whether they are published or not. The documents may come from teaching and research institutions in France or abroad, or from public or private research centers.
L'archive ouverte pluridisciplinaire HAL, est destinée au dépôt et à la diffusion de documents scientifiques de niveau recherche, publiés ou non, émanant des établissements d'enseignement et de recherche français ou étrangers, des laboratoires publics ou privés. 
This is a pre-copyedited PDF of an article accepted for publication in the Journal of Law and Society following peer review. The version of record [Journal of Law and Society, vol 46, Special Issue 1, 2019, 73-94] is available online at: https://onlinelibrary.wiley.com/doi/10.1111/jols.12184

\title{
Fixing Transnational Drug Policy Drug Prohibition in the Eyes of Comparative Law \\ Renaud Colson*
}

\begin{abstract}
Drug prohibition allows us to study over a significant period of time how penal provisions framed at a supranational level flow, settle and unsettle across different countries. At a time of growing doubt about the benefit of criminalisation of drug use, it also provides a case study as to how epistemic communities may rely on comparative research to identify best practices and promote them as normative alternatives in the face of a long entrenched legal dogma. In order to explore these issues, this article looks at the UN drug control system from the perspective of comparative law. It shows how the concept of legal transplant provides a useful tool to understand the limits of transnational criminal law designed on a global scale to tackle the 'drug problem', and it clarifies the various types of legal comparison that might contribute to addressing this failed transplant.
\end{abstract}

\section{ACKNOWLEDGMENTS}

This research benefited from a financial support of the Cardiff University International Visiting Fellow scheme and of the Max-Planck-Institut für ausländisches und internationales Privatrecht in Hamburg. I wish to thank Bhupinder Chimni, Stewart Field and Grégoire Mallard, who provided valuable insight in the course of the research, and Monica Roman for her copy-editing.

\section{INTRODUCTION}

Dating back to the first decades of the twentieth century, international drug control is one of the oldest multilateral treaty-based systems in existence. One way to characterize its development is to describe it as a collective effort to draw lessons from the "drug-problem" experienced in certain places in order to design and disseminate a policy to suppress drug abuse throughout the world. ${ }^{1}$ Such a narrative can draw on powerful images such as the development of a Chinese opium epidemic fuelled by colonial powers in the nineteenth century, the constitution of a long-lasting international ideological consensus on the "war on drugs", and the development of international treaties and multilateral bodies to tackle the scourge of drug abuse and drug trafficking. Compelling as it may be, this official account has nonetheless serious rivals. The finest historians of drug diplomacy usually consider the drug control treaties

\footnotetext{
* Faculté de droit et des sciences politiques de Nantes, Chemin de la Censive-du-Tertre - BP 81307, 44313 Nantes Cedex 3, France, Renaud.Colson@univ-nantes.fr

${ }^{1}$ T. Pietschmann, 'A Century of International Drug Control' (2007) LIX Bull. on Narcotics 1.
} 
less the rational result of judicious consideration of the 'drug problem' than the reflection of a myriad of economic, political, bureaucratic, and moral considerations. ${ }^{2}$ These observations provide the basis for an alternative description according to which the development of the drug control system has been essentially 'opportunistic'. ${ }^{3}$ Far from being the product of public health necessity, global prohibition may reflect the worldwide imposition of western values and the protection of (post)colonial industrial interests, ${ }^{4}$ both dimensions being reflected in the decoupling of illicit 'drugs' from alcohol and tobacco in the early $20^{\text {th }}$ century. ${ }^{5}$ This critical account of international drug control substitutes the official narrative of collective 'lesson drawing' for a grimmer version of one-sided 'lesson teaching' in which narcotics prohibition results from a dubious crusade carried out by a few influential states led by the USA. ${ }^{6}$

What both stories have in common is their relative lack of concern for the way legal norms, especially criminal provisions, flow between international and national legal orders and settle in domestic settings. In their defence, opening this legal black box may have looked superfluous. Legal scholarship itself, imbued with a sense of coherence and necessity, often tends to fix the meaning of rules in an abstract and permanent way, which discourages enquiry into how they circulate at a global level and are put into effect in local frameworks. Once in force, legal norms acquire a strong authoritative value as they give shared meaning and common orientation to people's understanding of the world. Regardless of their secular character, these rules are founded on dogma which hide from us their contingent nature. ${ }^{7}$ Such is the case for the criminalisation of various illicit drug-related activities, a principle which has acquired, over the years, a patina of religious self-evidence even in the eyes of the heretic observers who contest its legitimacy. ${ }^{8}$ Grounded in an almost universally accepted multilateral treaty-based system, this criminalisation ethos has admittedly benefited from a normative consensus at the global level. It is built into a suite of UN conventions ${ }^{9}$ which establish, among other things, a catalogue of offences. The letter of these treaties leaves little choice to the states but to incorporate a strong law enforcement dimension into their drug policy. Unsurprisingly, both the followers of the drug control system and those holding it in deep suspicion tend to take for granted that international drug conventions have spread a criminal policy around the world. But by doing so, both groups might have taken the law both too seriously, as a reliable tool for the transnational diffusion of an identified (and possibly misguided) standard of action, and not

\footnotetext{
${ }^{2}$ See esp. W.B. McAllister, Drug Diplomacy in the Twentieth Century: An International History (1999).

${ }^{3}$ L. Paoli, V. Greenfield, P. Reuter, 'Change Is Possible: The History of International Drug Control Regime and Implications for Future Policymaking' (2012) 47 Substance Use and Misuse 923.

${ }^{4}$ E.A. Nadelmann, 'Global Prohibition Regimes: The Evolution of Norms in International Society' (1990) 44 International Organization 479. And more recently C. Sanchéz-Avilés, O. Ditrych, 'The Global Drug Prohibition Regime: Prospects for Stability and Change in an Increasingly less Prohibitionist World' (2018) 55 International Politics 463.

${ }^{5}$ T. Seddon, 'Inventing Drugs: A Genealogy of a Regulatory Concept' (2016) 43 J. of Law and Society 393.

${ }^{6}$ D. Bewley-Taylor, The United States and International Drug Control: 1909 - 1997 (2001).

${ }^{7}$ A. Supiot (trans. S. Brown), Homo Juridicus: On the Anthropological Function of the Law (2007).

${ }^{8}$ On the religious nature of the drug control regime, see P. Cohen, 'The Drug Prohibition Church and the Adventure of Reformation' (2003) 14 International Journal of Drug Policy 213.

${ }^{9}$ The three major drug control treaties currently in force are the 1961 Single Convention on Narcotic Drugs, the 1971 Convention on Psychotropic Substances, and the 1988 United Nations Convention against Illicit Traffic in Narcotic Drugs and Psychotropic Substances.
} 
seriously enough, in overlooking the ways in which international norms adapt to diverse cultural settings. Indeed, there are good reasons to suspect that the global spread of the prohibitionist norm through legal instruments has never been a straightforward process.

In recent years, clear deviations to the orthodox understanding of drug control conventions have increased doubts about the ability to sustain the transnational imposition of a prohibitionist standard. Decriminalisation of illicit drug use, controlled distribution of heroin, legalization of cannabis or coca... These policies have been gaining ground in a growing number of countries. They are underpinned by a variety of arguments such as protecting the health of drug users, fighting organised crime, keeping drugs out of the hands of minors, making the criminal justice system more efficient, and even the preservation of cultural patrimony. ${ }^{10}$ As several states have relaxed their drug laws, sometimes to the point of the legalization of narcotics still banned under the drug control regime, the latter seems to have reached a point of unprecedented crisis. These divergences have been analysed from the perspective of international relations ${ }^{11}$ and international law. ${ }^{12}$ However, comparative law scholarship provides another vantage point to shed light on the historical rise and current weakening of the drug control system. Longstanding research on the unification of municipal laws and on legal transplants can provide useful insights into the controversial impact of UN drug control treaties on national jurisdiction. Moreover, decades of reflection on the proper use and limits of legal comparison offer useful resources to assess and possibly sharpen current comparative strategies in the field of drug policy research. Reciprocally, the study of drug prohibition from the perspective of comparative law can inform the ongoing methodological debates of the discipline. Drug prohibition is only one example among many of norms which travel across borders under the label of transnational criminal law. ${ }^{13}$ Yet because it was internationalised a long time ago, it offers the benefit of hindsight to reveal how penal provisions framed at a supranational level flow, settle and unsettle across different countries. At a time of growing doubt about the benefit of the criminalisation of drug use, it also provides a case study on how epistemic communities can rely on comparative research to identify best practices and to promote them as normative alternatives in the face of long entrenched legal dogma.

In order to explore these issues, this article looks at the UN drug control system from the perspective of comparative law. In a first part, it shows how the concept of legal transplant provides a useful tool to understand the limits of a transnational criminal law designed at a global scale to tackle the "drug problem". In a second part, the article seeks to clarify the various types of legal comparison that might contribute to the fixing of this failed transplant and to assess the impact of comparative research on drug laws.

\footnotetext{
${ }^{10}$ The cultural patrimony argument was used with regard to the legalisation of coca in Bolivia after it had been entrenched in the 2009 Constitution of the Bolivian state (Art. 384).

${ }^{11}$ D. Bewley-Taylor, International Drug Control: Consensus Fractured (2012).

${ }^{12}$ N. Boister, 'Waltzing on the Vienna Consensus on Drug Control? Tensions in the International System for the Control of Drugs' (2016) 29 Leiden Journal of International Law 389.

${ }^{13}$ D. Melossi, M. Sozzo, R. Sparks, 'Introduction. Criminal Questions: Cultural Embeddedness and Diffusion', in Travels of the Criminal Question: Cultural Embeddedness and Diffusion, eds. D. Melossi, M. Sozzo, R. Sparks (2011) 1.
} 


\section{FIXING TRANSNATIONAL DRUG POLICY WITH LEGAL TRANSPLANTATION: HOW CAN COMPARATIVE LAW EXPLAIN DRUG PROHIBITION?}

International drug control illustrates many of the pitfalls of transnational legal transplantation. It shows, from a realist perspective, how international instruments established to realize a noble ideal, namely a drug-free world, can be founded on erroneous beliefs and serve dubious strategies. It also reveals how the contingent and subsidiary use of criminal law can eventually come to dominate the core logic of a transnational regime. In the case of international drug control, this happened even though the criminal provisions of the treaties were shrouded in ambiguity in order to guarantee both their acceptance by, and their application in, states with very different legal cultures. As a result, the reception of the international model in domestic jurisdictions never really led to the unification of penal policies and very little was actually achieved in terms of legal harmonization. By and large, it is unclear how much the global diffusion of norms criminalizing illicit drug use and illicit drug trafficking has served the objective of the drug control treaties. But their reception in domestic settings had nonetheless important consequences, many of them unexpected, and some arguably malign. In this respect, the international drug control system demonstrates that social engineering through legal transfer of criminal norms can sometimes prove not only inefficient but also harmful.

\section{Contingency of the project}

The genesis of international drug control can be traced to the early $20^{\text {th }}$ century. ${ }^{14}$ At the time, international action for the control of narcotics owed much to the image of China as an opium slave, a 'locus classicus of the modern drug debate'. ${ }^{15}$ It also built upon a growing anxiety in western elites about the harmfulness and the immorality of popular drug use. These concerns may have been partly ill-founded, tainted by racism and social prejudice. ${ }^{16}$ They nonetheless struck a chord in American and European societies. Coupled with concomitant technical and corporatist developments in the fields of pharmacy, medicine and public health, the ideological shift led to the formulation of a sharp distinction between the legitimate (medical) use and the illegitimate (recreational) abuse of intoxicating drugs. The sequence then ran from the constitutions of pressure groups in individual countries to the convening of an international conference in Shanghai, the passing of resolutions, the adoption of treaties, and the setting up of an international bureaucracy under the umbrella of the League of Nations and, later, the United Nations. ${ }^{17}$

The idea that illicit drug activities should be criminalized was by no mean originally central to international drug control. From the onset, the concern of drug diplomacy was focused on the restriction of access to narcotics. ${ }^{18}$ Yet the first treaties contained no binding provision to this

\footnotetext{
${ }^{14}$ D. Lowes, The Genesis of International Narcotics Control (1966).

${ }^{15}$ F. Dikötter, 'Patient Zero': China and the Myth of the 'Opium Plague', Inaugural Lecture given at the School of Oriental and African Studies, University of London (2003), available at <http://frankdikotter.com/publications/the-myth-of-opium.pdf>.

${ }^{16}$ D.T. Courtwright, Forces of Habit: Drugs and the Making of the Modern World (2001) 168-173.

${ }^{17}$ K. Bruun, L. Pan, I. Rexed, The Gentlemen's Club: International Control of Drugs and Alcohol (1975) 8.

${ }^{18}$ The International Opium Commission held in Shangai in 1909, which was the first international conference convened to discuss narcotics, thus stated in its report that "the use of opium in any form
} 
effect. The use of opium in any form otherwise than for medical purpose was first deemed to be a matter "for careful regulation". ${ }^{19}$ Then the "gradual suppression of the abuse of opium morphine and cocaine" was contemplated. ${ }^{20}$ In the course of time, additional lists of substances considered particularly harmful were drawn up, starting with most traditional Southern drugs (e.g. cannabis), later joined by psychoactive substances newly synthetized in Western laboratories. But initially, international treaties required neither the interdiction of these intoxicating drugs nor their criminalisation. Instead they established commodity control through the creation and the regulation of a licit drug market restricted to legitimate purposes with the ambition to monitor supply and eliminate leakage. ${ }^{21}$

The underlying strategy of the first drug control conventions was that once excess supplies were eliminated from the licit market, drug abuse would dry up. Eventually, history proved this assumption naïve and the need for criminal law harmonization in order to suppress illicit activities emerged on the international agenda. A continuing disconnect between drug control effort and the social and medical issue of 'addiction' led to a hardening of the regime and the accommodation of the values of its most powerful stakeholders. One of its central bureaucratic organs, the Commission on Narcotic Drugs, stressed the need to impose harsh penalties on traffickers. ${ }^{22}$ The United States, which had long promoted the universalization of the prohibitionist policy it pursued at home, ${ }^{23}$ proved eager to harness the war on drugs as an instrument for advancing foreign policy interests and began to emphasize the danger of drug trafficking to national security. ${ }^{24}$ As drugs proved 'suitable enemies' for building consensus in international arenas, ${ }^{25}$ this was conducive to a shift towards a punitive rationality of international drug control. New treaties requiring penal action against illicit drug activities were negotiated. States were assigned the duty to treat or criminalize individual users and required to take action to reduce drug-related crime. ${ }^{26}$

Many countries did not wait for the development of a criminal component in the international drug control regime to sanction drug trafficking and drug use. Although a late comer in the history of modern criminal law, drug-related offences were established in many places in the first decades of the $20^{\text {th }}$ century. A normative settlement on the restriction of drug commerce by means of criminal law was thus established in western nations before it was solidified in drug control conventions. Far from being a top down and linear development, the propagation of the prohibitionist standard was in the first place a recursive process. Progressively though, the international drug control regime has provided building blocks for a transnational criminal

otherwise than for medical purpose is held by almost every participant country to be a matter for prohibition or for careful regulation (...) at progressively increasing stringency".

${ }^{19}$ Resolution 3 of the International Opium Commission held in Shangai in 1909.

${ }^{20}$ Preamble of the Hague Convention, 1912.

${ }^{21}$ J. Collins, 'Rethinking "Flexibilities" in the International Drug Control System: Potential, Precedents and Models for Reforms' (2018) 60 International J. of Drug Policy 107, at 111.

${ }^{22}$ Bruun, op. cit., n. 17, pp. 138-139.

${ }^{23}$ D. Musto, The American Disease: Origins of Narcotics Control (1999, $3^{\text {rd }}$ ed.), chap. 2.

${ }^{24}$ P. Andrea, E. Nadelmann, Policing the Globe: Criminalization and Crime Control in International Relations (2008) 236.

${ }^{25}$ R. Room 'The Rhetoric of International Drug Control' (1999) 34 Substance Use and Misuse 1689.

${ }^{26}$ C. Carstairs 'The stages of the international drug control system' (2005) 24 Drug and Alcohol Review 57. 
law including substantive norms and procedural measures. This created a ratchet effect on the law of the states parties which had already criminalised illicit drug activities and conferred considerable legitimacy on the penal treatment of drug issues elsewhere. Eventually, states had little option but to 'voluntarily' transplant prohibitionist laws into their national jurisdiction: with various incentives to adhere to the drug control conventions, ${ }^{27}$ these sovereign decisions were sometimes imposed though a mix of diplomatic and political inducements. ${ }^{28}$

But it is worth underlining that this increasing dominance of law enforcement came chronologically second and contingent to a regulatory regime whose main purpose was, in the first place, to establish a licit market. In this process, the 1961 Single Convention on Narcotic Drugs can rightly be regarded as a 'watershed' event marking a shift towards a stricter, more comprehensive and more repressive framework. ${ }^{29}$ Yet, however complex and precise the architecture of this regime may be, the treaties, soft law instruments, administrative resources and international bodies established to suppress illicit trafficking can hardly be said to define a full-fledged criminal policy. States parties to the international drug control regime acknowledge the distinction between licit and illicit markets and commit themselves to suppressing the latter, but the actual content of their international obligations remains, to a large extent, indeterminate.

\section{Indeterminacy of the model}

International attitudes to drug offenses have been one of progressive net-widening and harsher punishment. This process reveals itself in the three successive treaties which form the bedrock of the current dug control regime. The 1961 Single Convention on Narcotic Drugs broadly identifies various behaviours for criminalisation such as the illicit cultivation, production, possession, distribution, and exportation of narcotics. ${ }^{30}$ The 1971 Convention on Psychotropic Substances opts for an open-ended approach by requiring that 'any action contrary to a law or regulation adopted in pursuance of (...) this Convention" shall be treated as "a punishable offence'. ${ }^{31}$ Finally, the 1988 Convention against Illicit Traffic requires parties 'to establish a modern code of criminal offences relating to the various aspects of illicit trafficking and to ensure that such illicit activities are dealt with as serious offences' ${ }^{32}$ In order to pursue this project, the 1988 Convention enumerates new criminal conducts such as property conversion and the laundering of the profits of trafficking. It ambitiously enlarges the circle of criminal liability to include all persons who induce, assist, shelter or finance the illicit consumption of drugs, and criminalizes drug users themselves. ${ }^{33}$ Last but not least, the Convention contains extensive provisions for co-operation in respect of enforcement and prosecution of offenders.

\footnotetext{
${ }^{27}$ Economic coercion by way of the threat of aid withdrawal being one of the most efficient as evidenced by the US drug certification process. On this, see J. Ayling, 'Conscription in the War on Drugs: Recent reforms to the U.S. drug certification process' (2005) 16 International J. of Drug Policy, 376.

${ }^{28}$ N. Boister, 'Transnational Criminal Law?' (2003) 14 European J. of International Law 953, at 960.

${ }^{29}$ D. Bewley-Taylor, M. Jelsma 'Regime change: Re-visiting the 1961 Single Convention on Narcotic Drugs' (2012) 23 International Journal of Drug Policy, 72.

${ }^{30}$ Art. 36, Single Convention on Narcotic Drugs, 1961.

${ }^{31}$ Art. 22, Convention on Psychotropic Substances, 1971.

${ }^{32}$ Commentary on the United Nations Convention against Illicit Traffic in Narcotic Drugs and Psychotropic Substances (1988) UN DOC. E/CN.7/590, 48.

${ }^{33}$ D.W. Sproule, P. St-Denis, 'The UN Drug Trafficking Convention: An Ambitious Step' (1989) 27

Canadian Yearbook of International Law 263.
} 
All three conventions provide penological guidelines expressing a pursuit of greater severity as serious drug-related offences shall be 'liable to adequate punishment particularly by imprisonment or other penalties of deprivation of liberty'. ${ }^{34}$ Other provisions are intended to ensure that the offences established are matched by appropriately severe penalties so as to have the desired deterring and retributive effects. ${ }^{35}$

This legal arsenal establishes punitive drug prohibition on a global scale. ${ }^{36}$ It represents a dramatic extension of the criminalisation of drug-related behaviours. Yet its normative content remains to a large extent indeterminate and has to be specified by national legislators. Indeed, the conventions are not self-executing. They do not create individual penal responsibility. Instead they establish an indirect system of interstate obligations which relies on states' transposition of international provisions into domestic law. The skeleton of offences and of penalties set down in the conventions provides only a template which has to be fleshed out in the domestic law of the states parties. The vagueness of the international criminal provisions seems to have been a necessary condition for making them acceptable to negotiating parties with distinct systems of substantive and procedural law. ${ }^{37}$ The compromise accommodates different grammars of criminal law, especially opposing civil law and common law approaches. But this came at the cost of explicitness and the result has been relative legal ambiguity and very limited developments on the scope and conditions of criminal liability (e.g. elements of conduct, fault, criminal capacity...).

Owing to its open texture and its lack of precision, international drug control law can, at the most, claim to achieve loose harmonisation of domestic criminal laws, not to mention sentencing policies. It is unclear even to what extent such a convergence is actually required by the treaties. For in addition to the indeterminacy of the criminal provisions, all three conventions include escape clauses which weaken their normative capacity. Pacta sunt servanda and the principle of effectiveness constrain all signatories to adopt a punitive-oriented legal framework. But a close look at the text reveals that, although formally binding, the penal provisions prove remarkably soft. Regardless of national reservations, states parties only have the obligation to criminalize enumerated conducts insofar as it does not violate their 'constitutional principles' and subject, in some cases, to 'the basic concepts of (their) legal system'. ${ }^{38}$ The scope of international obligations is thus open to national variation.

The drugs conventions prove, at least from a strictly legal perspective, to be "full of holes" 39 and liable to diverging interpretations. ${ }^{40}$ Nonetheless, they have an important impact on national

\footnotetext{
${ }^{34}$ Comp. Art. 36, Single Convention on Narcotic Drugs, 1961; Art. 22, Convention on Psychotropic Substances, 1971; Art. 3, United Nations Convention against Illicit Traffic in Narcotic Drugs and Psychotropic Substances, 1988.

${ }^{35}$ See esp. Art. 3(5), United Nations Convention against Illicit Traffic in Narcotic Drugs and Psychotropic Substances, 1988.

${ }^{36}$ For a thorough examination, see N. Boister, Penal Aspects of the UN Drug Conventions (2001).

${ }^{37}$ Commentary on the Single Convention on Narcotic Drugs, 1961 (1973) UN DOC. E/CN.7/588, 425.

38 Art. 3(1)(c) and 3(2), United Nations Convention against Illicit Traffic in Narcotic Drugs and Psychotropic Substances, 1988.

${ }^{39}$ Boister, op. cit., n. 36, p. 524.

${ }^{40}$ On the fundamental indeterminacy of international law, see the work of M. Koskenniemi, esp. From Apology to Utopia: The Structure of International Legal Argument (2005), 590-596.
} 
legislations. Coupled with the official UN commentaries and the restrictive reading of the International Narcotics Control Board annual reports, ${ }^{41}$ they have contributed to the dissemination of a prohibitionist ideology and a repressive model of drug policy. But the extent of the convergence between domestic legal frameworks remains unclear. It is generally acknowledged among comparatists that transfers of norms are affected by local interests, mentalities and institutions. ${ }^{42}$ The impact of the same legal transplant can be very different from one setting to the other. It is therefore not surprising that in spite of a decades-old project to promote a transnational penal response to illicit drug activities, worldwide diversity still prevails. National drug policies range on a continuum from very punitive forms of drug prohibition to more tolerant and health-oriented approaches. In that respect, international obligations seem to be less of an influence than other local cultural determinants ${ }^{43}$ such as procedural traditions, policing and sentencing practices, and more generally, the role of expertise and the weight of medical science in framing public policy, the access of social movements to the locus of public power... In that respect, the local implementation of the global transplant has not only proved unpredictable, it also came with unintended consequences.

\section{Malign effects of the transplant}

The worldwide criminalisation of drug activities has been criticized in the light of the poor results of the drug control regime. Indeed, although regularly reaffirmed by the international community in hortatory political declarations, ${ }^{44}$ the ambitious objective of significantly reducing both the illicit supply of and the demand for drugs appears more than ever out of reach. The United Nations agencies have implicitly acknowledged this failure in the last decade, avoiding any claim of success; the global situation is usually described as generally stable with regard to the prevalence of illicit drug use and 'expanding and diversifying as never before' with regard to illicit dug markets. ${ }^{45}$ In addition to these disappointing results, leaders of the international drug control system have acknowledged some malign consequences of the criminological model propagated by global prohibition.

\footnotetext{
${ }^{41}$ See for example the Report of the International Narcotics Control Board for 1996 with a special chapter on 'Drug Abuse and the Criminal Justice System' UN DOC E/INCB/1996/1, or the Report of the International Narcotics Control Board for 2007 with a special chapter on 'The Principle of Proportionality and Drug-Related Offences' UN DOC E/INCB/2007/1. More generally, on the ideological role of the INCB annual report, see Bewley-Taylor, op. cit., n. 11, pp. 224-249.

${ }^{42}$ On this, see M. Graziadei, 'Comparative Law as the Study of Transplants and Receptions', in Oxford Handbook of Comparative Law, eds. M. Reimann \& R. Zimmerman, $\left(2019,2^{\text {nd }}\right.$ ed.) chap. 16. Comp. D. Nelken, 'Comparatists and Transferability', in Comparative Legal Studies: Traditions and Transitions, eds. P. Legrand \& R. Munday (2003), 437.

${ }^{43}$ Europe provides a telling example of how national cultures put up resistance to this harmonization. In spite of an ancient cultural heritage and a decades long political integration process, including a common drug policy, European states have developed very different types of criminal justice responses to drugs issue. On this diversity, see R. Colson, H. Bergeron (eds), European Drug Policies: The Ways of Reform (2017).

${ }^{44}$ See for example the recent Outcome Document of the 2016 United Nations General Assembly Special Session on the World Drug Problem: Our joint commitment to effectively addressing and countering the world drug problem (2016)

${ }^{45}$ World Drug Report 2018, UN DOC E.18.XI.9.
} 
In 2008, the executive director of the United Nations Office on Drug and Crime (UNODC), Antonio Maria Costa, the United Nations drug czar, listed several unintended consequences of the system. ${ }^{46}$ The first one is the creation of 'a huge criminal black market that now thrives in order to get prohibited substances from producers to consumers'. The second one relates to the displacement of public health policy to the background as public security and law enforcement is perceived as the primary way of solving drug issues. The third unintended consequence has to do with geographical displacement, the so-called balloon effect which links tighter controls on production in one place to increase in other places. 'Substance displacement' is the fourth consequence: the stringent control of one drug moves suppliers and users to other psychoactive substances, which are sometimes more dangerous. Last but not least, the fifth unintended consequence is the "marginalization of drug users": "a system appears to have been created in which those who fall into the web of addiction find themselves excluded and marginalized from the social mainstream, tainted with a moral stigma, and often unable to find treatment even when they may be motivated to want it".

This uncompromising assessment, which has been confirmed by many research findings, ${ }^{47}$ strengthens the thesis that global prohibition has led to some sort of 'criminal iatrogenesis', the 'harmful results of well-intentioned crime control practice' through a process of 'deviancy amplification'. ${ }^{48}$ These unintended, if not unexpected, consequences have turned drug prohibition into a 'self-fulfilling prophecy'49 as punitive drug laws have produced the public health and criminogenic consequences that fuel public fears and moral condemnations, and thus the need for punitive prohibition.

This in itself may not be enough to brand the criminalisation of illicit drug-related activities a 'malicious transplant', a category which requires a subjective desire to do harm. ${ }^{50}$ Even if some governments use the war on drugs to promote discriminatory law enforcement policies ${ }^{51}$ or to carry out extra-judicial killings, ${ }^{52}$ these policies cannot be seriously attributed to the diffusion of transnational prohibitionist framework. On the contrary, the International Narcotic Control Boards, the watchdog of the drug control treaties, appeal to 'all States to address drug-related crime through formal criminal justice responses, in accordance with the Universal Declaration of Human Rights (...), and in adherence to internationally recognized due process standards' ${ }^{53}$ Yet, when the same body makes use of selective evidence and dubious interpretations of the UN conventions to criticize harm-reduction policies such as drug consumption rooms or heroin

\footnotetext{
${ }^{46}$ A.M. Costa, 'Making drug control 'fit for purpose': Building on the UNGASS decade' (2008) UN DOC E/CN.7/2008/CRP 17.

${ }^{47}$ P. Reuter, The Unintended Consequences of Drug Policies (2009), RAND Europe.

${ }^{48}$ B. Bowling, 'Transnational Criminology and the Globalization of Harm Production', in What is Criminology?, eds. M. Bosworth, C. Hoyle (2011) 361.

${ }^{49}$ C. Reinarman, 'Criminal Law and Cultural Lag: Drug Prohibition as Anachronism', in Die Sinnprovinz des Kriminalität: Zur Dynamik eines sozialen Feldes, eds. H. Schmidt-Semish, H. Hess (2014) 67, at 73.

${ }^{50}$ M. Siems, 'Malicious legal transplants', Legal Studies 38 (2018), 103.

${ }^{51}$ D.M. Provine, 'Race and Inequality in the War on Drugs' Annual Review of Law and Social Science 7 (2011) 41.

52 D. Reyes, 'The Spectacle of Violence in Duterte's "War on Drugs", Journal of Current Southeast Asian Affairs 35 (2016) 111.

${ }^{53}$ International Narcotics Control Board, Report 2018, UN DOC E/INCB/2018/1, 110.
} 
maintenance programme, ${ }^{54}$ the diffusion of a rigid transnational prohibition is revealing itself to be, if not malicious, then certainly malign.

More generally, a comparative and historical perspective on normalised drug use in various communities around the world raises disturbing questions about the 'malignant colonialism' 55 associated with global prohibition. From the beginning, the list of controlled substances, and the definition of deviance they convey, bore testament to the cultural and racial prejudices of the moral entrepreneurs who promoted their interdiction in the early $20^{\text {th }}$ century. Synthetic substances produced in industrial nations eventually joined the ranks of the scheduled drugs of the people of Asia, Africa and Latin America. Yet some still detect a western ethnocentric bias and a neo-colonial aspect of the international drug control conventions. Without a doubt, the universalising statements on the intrinsic evil of drugs overlook the existence of contexts 'beyond the west' where traditional forms of drug use provide an integrative and positive contribution to group solidarity and community structure. ${ }^{56}$ But subaltern voices which claim that, at least in some places, the misery of drug taking followed, rather than preceded, the diffusion of a world-wide criminal law-based prohibition are barely heard.

\section{FIXING TRANSNATIONAL PROHIBITION WITH COMPARISON: CAN COMPARATIVE ANALYSIS IMPROVE DRUG POLICY?}

In the light of the poor results of the prohibitionist legal transplant, it is not surprising that comparative research on drug policy has vigorously developed in the last decades. Split between pharmaceutical law and criminal law, legal scholarship on illicit drugs never reached a mass critical enough to establish the subject as a branch of law. But addiction science has significantly contributed to the comparative study of drug laws. Although not a discipline in its own right, ${ }^{57}$ rather a locus of interdisciplinary collaboration, the field of addiction has grown tremendously in the past 35 years, both globally and in specific countries. An increasingly broad church with academic programs, professional organizations, advocacy groups, research and monitoring centres, and communication channels including more than 100 scholarly journals, ${ }^{58}$ this epistemic community has an authoritative claim to policy-relevant knowledge within the domain of addiction. ${ }^{59}$ This claim has been bolstered by the production of an important body of drug policy analysis, some of it anchored in transnational comparison. While this comparative corpus remains piecemeal and mainly focuses on developed societies, it is now

\footnotetext{
${ }^{54}$ Bewley-Taylor, op. cit. n. 11, pp. 224-240.

${ }^{55}$ S. Cohen, 'Western Crime Control Models in the Third World: Benign or Malignant?', in Reseach in Law, Deviance and Social Control, eds. S. Spitzer, R. Simon (1982), 85.

${ }^{56}$ R. Coomber, N. South (eds.), Drug Use and Cultural Contexts 'Beyond the West': Tradition, Change and Post-Colonialism (2004). See also the special issue on 'Drugs, politics and society in the Global South' of the Third World Quarterly 39 (2018).

${ }^{57}$ Addiction science, because it encompasses a wide range of methods and projects, lacks the 'stable and delimited field' required to establish an academic discipline. On the notion of discipline, see P. Bourdieu (transl. R. Nice) Science of Science and Reflexivity (2004), 64-65.

${ }^{58}$ T.F. Babor et al., 'Infrastructure and Career Opportunities in Addiction Science: The Emergence of an Interdisciplinary Field', in Publishing Addiction Science: A Guide for the Perplexed, eds. T.F. Barbor, Babor, K. Stenius, R. Pates, M. Miovský, J. O’Reilly, P. Candon (2017).

${ }^{59}$ On epistemic communities as locus of authoritative knowledge, see P.M. Hass, 'Policy Knowledge: Epistemic Communities', International Encyclopaedia of the Social \& Behavioral Sciences, eds. N.J. Smelser \& B. Baltes (2001) 11578.
} 
sufficiently dense to qualify as an autonomous field of study. ${ }^{60}$ In spite of the often interdisciplinary nature of this work, which draws on policy studies, epidemiology, economics and sociology, one can argue that much of it falls within the ambit of comparative law as it provides knowledge on the content, the implementation and the effect of legal norms concerning illicit drugs in various countries. Unsurprisingly, this research raises epistemological issues in relation to its aims, methods and results, which echo those debated by comparative law scholars.

\section{Aims of comparison}

Standard comparative law textbooks are prone to emphasize that the first aim of their discipline is disinterested knowledge. ${ }^{61}$ Describing national drug policies, analysing the genesis and development of domestic drug laws, unveiling their similarities and differences are indeed legitimate scientific goals per se, and many books and journal articles seem to confine themselves to this task. In this case, the goal is firstly to learn 'about' drug laws in different places, and secondly to understand 'why' they develop the way they do. But this descriptive and explanatory approach often goes one step further to evaluate the laws under review.

The idea that comparative lawyers should engage in policy assessment is sometimes contested because it means being judgmental about legal systems with very different cultural orientations, ${ }^{62}$ a stance often disliked by comparatists who praise themselves for being sensitive about, and respectful of, cultural diversity. Yet it is also traditionally held that 'the comparatist is in the best position to follow his comparative researches with a critical evaluation'. ${ }^{63}$ Consequently, while mainstream comparative law is usually careful to distance itself from the choices of political life and the work of governance, ${ }^{64}$ it also claims to learn 'from' different legal frameworks in terms of outcomes and effectiveness. Accordingly, much comparative research on drug law aspires to contribute to the evaluation and refinement of policy. This is especially remarkable in the case of research institutions established for the purpose of providing policy advice. Such is the case of the European Monitoring Centre on Drugs and Drug Addiction and its national observatories: the mission of this European agency is to supply comparable information on the legal responses to drugs at a European level in order to offer policymakers the data they need for drawing up informed drug laws and strategies, and to pinpoint best practice. ${ }^{65}$

Like comparative law scholars, most drug policy researchers are prone to emphasize that their contribution is 'about knowing, not doing': ${ }^{66}$ they usually stand for scientific evidence, and even when they claim to incorporate a 'public good' perspective as an added consideration in

${ }^{60}$ A. Ritter, M. Livingston, J. Chalmers, L. Berends, P. Reuter, 'Comparative Policy Analysis for Alcohol and Drugs: Current State of the Field', International J. of Drug Policy 31 (2016) 39.

${ }^{61}$ K. Zweigert, H. Kötz (transl. T. Weir), An Introduction to Comparative Law (1998, $3^{\text {rd }}$ ed.), 15. See also, M. Siems Comparative Law (2018, $2^{\text {nd }}$ ed.) 2.

${ }^{62}$ P. de Cruz, Comparative Law in a Changing World (2007) 224.

${ }^{63}$ K. Zweigert, H. Kötz, op. cit., 47.

${ }^{64}$ D. Kennedy, 'The Methods and the Politics', in Legrand \& Munday, op. cit., n. 42, 349.

${ }_{65}$ European Monitoring Centre for Drugs and Drug Addiction, at http://www.emcdda.europa.eu/about/mission

${ }^{66}$ Kennedy, op. cit., n. 64, p. 346. 
the formulation of drug policy, they are eager to abstain from any definitive prescription and to emphasize that 'policy making should not be solely a technocratic endeavour entrusted to scientists' ${ }^{67}$ But there is little doubt that comparative research leads to normative conclusions, especially when it highlights the success of certain measures and warns against the ineffectiveness of others.

In practice, the three goals assigned to comparison - description, evaluation and transformation of the law - are often intertwined. On the one hand, researchers who develop in-depth comparative descriptions of drug policies are inclined to make value judgments. ${ }^{68}$ On the other hand, comparative arguments developed to promote policy change have to rely on an adequate description of case studies in order to strengthen their case. ${ }^{69}$ Finally, an evaluation of drug laws which relies on comparison requires a proper understanding of the legal frameworks being compared and is usually accompanied by at least implied recommendations. ${ }^{70}$ This entanglement of descriptive, evaluative and prescriptive discourses calls for particular scrutiny of the logical hierarchy between the various goals of any comparison. Political hegemony has always featured high among the various aims of comparative law and it is not uncommon for comparative arguments to be used for strictly political purpose, in order either to conserve or to change the law. ${ }^{71}$ Unsurprisingly, such comparisons may lead to the sacrifice of impartiality in description and evaluation.

An example of such biased comparison can be found in a 2007 report published by the UNODC on Sweden's Successful Drug Policy. ${ }^{72}$ Claiming strong evidentiary support, ${ }^{73}$ the report claimed to demonstrate a 'clear association between a restrictive drug policy and low levels of drug use' 74 and went so far as to ascribe the 'remarkable result' of Swedish policy to an 'ambitious vision' of a 'drug-free society'. ${ }^{75}$ The work relies inter alia on a comparison of drug use levels in Sweden with European averages to conclude that a deficit in drug control will translate into an increased 'drug problem' ${ }^{76}$ The fact that this reasoning rests upon a shaky scientific basis and that the Swedish success story has no foundation in empirical data, as was later demonstrated, ${ }^{77}$ did not prevent the UN agency from giving it weight and lustre by publishing it with a preface by its Executive Director.

\footnotetext{
${ }^{67}$ T.F. Barbor et al., Drug Policy and the Public Good (2018, $2^{\text {nd }}$ ed.) 251.

${ }^{68}$ See for example B. Caiuby Labate, C. Cavnar, T. Rodrigues (eds), Drug Policies and the Politics of Drugs in the Americas (2016), esp. the "Foreword".

${ }^{69}$ See for example N. Eastwood, E. Fox, A. Rosmarin, A Quiet Revolution: Drug Decriminalisation across the Globe (2016).

${ }^{70}$ See for example EMCDDA, Alternatives to punishment for drug-using offenders (2015).

${ }^{71}$ U. Kischel, Comparative Law (transl. A. Hammel) 2019, 47.

${ }^{72}$ UNODC, Sweden's Successful Drug Policy: A Review of the Evidence (2007)

73 The report is subtitled 'A Review of the Evidence' and its authors claim to "thoroughly review the available evidence, including data on drug abuse, dating back to the 1940s", id., p. 7.

${ }^{74} \mathrm{Id}$.

${ }^{75}$ Id., p. 52.

${ }^{76}$ P. Cohen, 'Looking at the UN, Smelling a Rat' 2 (2010) Amsterdam Law Forum 10 (2010).

${ }^{77}$ B. Olsson, 'Dressed for Success? A critical review of "Sweden's Successful Drug Policy: A Review of the Evidence"' (UNODC, 2007)' (2009) Paper presented at $3^{\text {rd }}$ ISSDP Conference, Vienna.
} 
This UNODC report illustrates the complexity of the research/policy nexus in the international drug control regime, ${ }^{78}$ a realm in which the functioning of the established bureaucracy does not seem favourable to in-depth scientific debate, let alone critical thinking. ${ }^{79}$ The dual role of UNODC, which acts both as centre for research and dissemination and as outlet for political messages, is partly to blame for this 'hopeful constructivism' the purpose of which is to reconfigure reality. ${ }^{80}$ But the use of faulty comparative arguments to blur the boundary between factual knowledge and untested beliefs is not limited to international bureaucracy. In this regard, the Swedish report reminds us that good comparative research starts with the ability to identify flawed comparisons. In order to unveil the duplicity of defective arguments, it is crucial to take methods seriously.

\section{Methods of comparison}

Comparative research on drug policies seems to have been relatively unconcerned with issues of method until now. Apart from the newness of the field, a reason for this lack of interest lies in the fact that this area of research brings together researchers from various disciplines. Each of them armed with their own tools, they tend to take for granted that the others are equally properly equipped, which allows the circulation of scientific statements between them while ignoring the possibility of furthering common reflection on the types of investigation applicable to their common topic. In this respect, comparative drug policy research stands in sharp contrast with comparative law scholarship, a discipline beset by epistemological self-questioning which provides abundant reflections on its methods. ${ }^{81}$ Yet, both fields share a remarkable lack of unity. In spite of recent attempts to clarify the scope and limits of comparative drug policies, definitional issues and fuzzy boundaries exist similar to those affecting the field of comparative law.

This variety is owed partly to the diversity of objects under analysis. Even if one confines drug policy to its legal components, law-like rules such as treaty, statute, regulation, order, guideline, standard operating procedure or other formalizing text, to the exclusion of informal organizational practices or routine functions, the field still covers a vast array of subjects with little in common with each other. Thus, comparative research on drug law spans a macro-micro continuum with some studies at one end focusing on the UN drug control institutions as a whole (compared with other international instruments such as climate change or human rights

\footnotetext{
${ }^{78}$ C. Hallam, D.R. Bewley-Taylor, 'Mapping the World Drug Problem: Science and politics in the United Nations drug control system', International J. of Drug Policy 21 (2010) 1.

${ }^{79}$ C. Fazey, 'The Commission on Narcotic Drugs and the United Nations International Drug Control Programme: Politics, policies and prospect for change 14 (2003) International J. of Drug Policy 155. See also F. Thoumi, 'Can the United Nations Support 'Objective' and Unhampered Illicit Drug Policy research', Crime, Law and Social Changes 38 (2002) 177.

${ }^{80}$ More generally, on the role of ignorance and knowledge and their instrumentalization in international politics, see G. Mallard, L. McGoey, 'Strategic Ignorance and Global Governance: An Ecumenical Approach to Epistemologies of Global Power', British J. of Sociology 69 (2018) 884.

${ }^{81}$ See, among many others, M. Adams \& D. Herbaut (eds) The Method and Culture of Comparative Law: Essays in Honour of Mark Van Hoecke (2014); M. Adams \& J. Bomhoff, Practice and Theory in Comparative Law (2012); Reimann \& Zimmerman, op. cit., n. 42; Legrand \& R. Munday, op. cit., n. 42.
} 
regimes $)^{82}$, and others concentrating on a specific measure implemented in local settings (e.g. impact of opposing cannabis policies in two different cities) ${ }^{83}$ at the other end. In between these two poles, comparative research can be carried out at various geographic levels (regional, national, or municipal) and focus on comprehensive policies or particular regulations.

Adding to this diversity of objects, comparative studies on drug policy are characterized by a plurality of approaches. Heterogeneity seems to prevail over any orthodoxy in this field of study. ${ }^{84}$ In this respect, drug policy research mirrors the increasing diversity of comparative law scholarship. ${ }^{85}$ The way institutional norms and legal standards are identified, described and eventually compared varies very much from study to study. Qualitative analysis sits alongside quantitative approach and case-oriented investigations compete with variable-oriented research.

Such methodological pluralism questions the existence of a scientific 'logic' shared by researchers working in this field ${ }^{86}$ There is indeed little in common between the thick cultural description of the historical development of national drug laws ${ }^{87}$ and the production of composite harm indexes designed to monitor and compare the social cost of these legal frameworks. ${ }^{88}$ Likewise, mapping studies which chart the characteristics of national legal frameworks and lead to the construction of typologies of domestic drug policies ${ }^{89}$ requires a different methodology from implementation studies which assess the concordance between law in the books and law in action, ${ }^{90}$ or from impact assessment studies which purport to highlight statistical association between specific policies and their population-level effects on the basis of complex statistical model specifications and mathematical formulae. ${ }^{91}$ The comparative process itself, a quest for similarities and differences, can be carried out along very different lines. Comparison is sometimes merely implied, especially in works which proceed by

${ }^{82}$ D. Bewley-Taylor, M. Fitzmaurice, 'The Evolution and Modernisation of Treaty Regimes: The Contrasting Cases of International Drug Control and Environmental Regulation' 20 International Community Law Review (2018) 403.

${ }^{83}$ C. Reinarman, P. Cohen, H. Kaal, 'The Limited Relevance of Drug Policy: Cannabis in Amsterdam and in San Francisco' 94 American J. of Public Health (2004) 836.

${ }^{84}$ Ritter et al., op. cit., n. 60.

${ }^{85}$ M. Siems, 'New Directions in Comparative Law', in Reimann \& Zimmermann, op. cit., n. 42, p. 852.

${ }^{86}$ More specifically, on the divide between those analysing a large number of cases on a few characteristics and those studying a few cases in depth, see D. della Porta, 'Comparative analysis: caseoriented versus variable-oriented research', in Approaches and Methodologies in the Social Sciences: A Pluralist Perspective, eds. D. della Porta \& M. Keating (2008), 198.

${ }^{87}$ See for example T. Boekhout van Solinge, Dealing with Drugs in Europe. An Investigation of European Drug Control Experiences: France, the Netherlands and Sweden (2004). See also Colson \& Bergeron (eds.), op. cit., n. 43.

${ }^{88}$ A. Ritter, 'Methods for Comparing Drug Policies: The Utility of Composite Drug Harm Indexes' 20 International J. of Drug Policy (2009) 475.

${ }^{89}$ See for example T. Ysa et al., Governance of Addictions: European Public Policies (2014). See also S. Callaghan, 'Issues in Comparing National Drug Policies: Utilizing Typologies to Identify Drug Policy Regimes and Explore Cultural Contexts' (2019) paper presented at $13^{\text {th }}$ ISSDP Conference, Paris.

${ }^{90}$ V. Belackova, A. Ritter, M. Shanahan, C.E. Hughes, 'Assessing the Concordance Between Illicit Drug Laws on the Books and Drug Law Enforcement: Comparison of Three States on the Continuum from "Decriminalised" to "Punitive"" (2017) 41 International J. of Drug Policy 148.

${ }^{91}$ Y. Shi, M. Lenzi, R. An 'Cannabis Liberalization and Adolescent Cannabis Use: A Cross-National Study in 38 Countries' (2015) 10 PLoS ONE, at: https://doi.org/10.1371/journal.pone.0143562. 
juxtaposition, or in studies of foreign law which simply describe specific sets of rules applicable to drug activities in a particular place. In contrast, sometimes comparison is highly formalized and expressed in numerical figures and ratio variances supposed to symbolize the different consequences of various policies.

In the light of this diversity, recent attempts have been made to better identify the boundaries and to streamline the methods of comparative research on drug policies. ${ }^{92}$ Such efforts are useful to promote debate and collaboration among researchers and to bolster the academic legitimacy of an interdisciplinary field in the making. Paradoxically though, it is unclear what theoretical gain such a methodological enterprise can achieve except the lowering of overambitious expectations.

Decades of methodological haggling in comparative law and comparative politics can serve as a useful warning against global theories and general truths based upon cross-national comparisons. Yet much of drug policy analysis appears to rely on it as an ideal way, for want of randomized control trials, to measure the efficiency of specific legal responses to particular drug issues. A comparative perspective can indeed contribute to demonstrating that some measures make a positive difference in some places. ${ }^{93}$ But regarding criminal laws, researchers tend to overestimate the comparability of national frameworks. Comparing criminal policies not only requires reliable institutional and criminological data, a challenge in itself as the target of these policies is illegal activity, but also a proper understanding of the various social and cultural contexts in which legal governance is taking place. ${ }^{94}$ Without such a contextual understanding, defining law as an independent variable likely to explain the 'efficiency' of a drug policy amounts to crude functionalism, an approach discredited even among comparative lawyers who take the functional method seriously. ${ }^{95}$

\section{Impact of comparison}

The routine expectation that addiction research, including comparative analysis, will influence drug policy often proves wrong. Thus, although comparative evidence tends to demonstrate the modest effect of criminal justice systems in deterring or reducing illicit drug use and drug trafficking, aggressive enforcement activities still consume the largest share of illicit drugrelated government spending in many countries. ${ }^{96}$ In order to understand this discrepancy, a burgeoning literature has explored the cognitive bias and associated forms of self-deception produced in the shaping of domestic drug policy. In this area where evidence is often difficult to locate and can appear spurious, the institutional claims of 'evidence-based policy' are derided by scholars who document how available data is selected and often distorted by policy-makers

\footnotetext{
${ }^{92}$ Ritter et al., op. cit, n. 60, and the reply by S. Burris, 'Theory and Methods in Comparative Drug and Alcohol Policy Research: Response to a Review of the Literature', International J. of Drug Policy 41 (2017), 126.

${ }^{93}$ Comparison has indeed proved crucial to demonstrate the effectiveness of specific strategies and interventions to reduce drug use and related harm such as opioid substitution therapy or needle exchange programmes. For a summary of the evidence, see T. Barbor et al., op. cit. n. 67, chap. 9.

${ }^{94}$ D. Nelken, Comparative Criminal Justice: Making Sense of Difference (2010).

${ }^{95}$ R. Michaels, 'The Functional Method of Comparative Law', in Reimann \& Zimmermann, op. cit., chap. 13.

${ }^{96}$ T. Barbor et al., op. cit. n. 67, chap 10
} 
and civil servants for the maintenance of their own status. ${ }^{97}$ This observation explains why comparative drug policy research is now taking a reflexive turn to answer questions about the shaping of drugs policy and the role that scientific evidence can play in that process. ${ }^{98}$

By and large, the conditions under which knowledge and expertise can influence policy making is always dependent upon non-scientific constraints, such as the structure of the political system, societal values and other contingent variables. ${ }^{99}$ In the case of illicit drugs, additional obstacles tend to make research even less appealing to politicians and civil servants. Observation is harder than with licit substances and data are scarcer, which make studies less reliable and possibly less persuasive. ${ }^{100}$ The use of research is also impeded by the moral stigma attached to illicit drug-related activities. The "drug problem" is still often perceived as one of crime, not primarily of health, and in times of penal populism, tough law enforcement based on justice consideration needs little empirical justification. Yet, in spite of these hurdles, it is probable that addiction research will see its impact on policy making grow in the future. The drug debate still has, and will probably retain, important moral and ideological dimensions but these increasingly coexist with an evaluation-based model. The core belief that drug use is a lasting anthropological fact which should be dealt with in the light of available scientific evidence rather than mere moral considerations is now firmly grounded in the public sphere, and the networks of transnational addiction science experts constitute an epistemic community with enough leverage for generating authoritative knowledge and developing policy entrepreneurship on drug issues both at the national and international level. ${ }^{101}$ In this transnational research community, cross-cultural comparisons play a crucial role in accelerating the circulation of policy ideas and legal models. At a time of declining faith in prohibition and openness to drug policy innovation, a window of opportunity is opening up to increase the impact of comparative research on drug policy.

There are several points at which comparative legal knowledge may impact on drug policy making, the most visible being the adoption of foreign policies and the transposition of external norms by national legislators. An example is the current relaxation of cannabis laws which is taking place in various places, sometimes heading towards its full legalization. The growing body of comparisons of existing regulatory models can hopefully inspire national legislators if only to weaken the ideological taboo of legalization still present in many countries, to fuel political debates and lend credibility to arguments used abroad to underpin policy change, and to map out possible policy options. Thus, while different cultural and political contexts necessarily lead to different types of reform in different places, comparative research on these

\footnotetext{
${ }^{97}$ M. Monaghan, Evidence versus Politics: Exploiting Research in UK Drug Policy Making? (2011). See also A. Stevens, Drugs, Crime and Public Health (2011), esp. Chap. 4.

${ }^{98} \mathrm{~J}$. Holmes, 'Introduction to a new series on case studies on the addiction policy process', Addiction 113 (2018) 1381.

${ }^{99}$ For a general perspective on these variables, see P. Cairney, Understanding Public Policy: Theories and Issues (2012), esp. chap. 11.

${ }^{100}$ P. Reuter, 'Why does research have so little impact on American drug policy?' 96 Addiction (2001) esp. 374.

${ }^{101}$ D. Alimi, "'Going Global”: Policy Entrepreneurship of the Global Commission on Drug Policy', 93 Public Administration (2015) 874.
} 
reforms can determine the very possibility of changes and influence the policy process 'elsewhere'.

A more discreet type of influence relates to the jurisprudence of higher courts. In a fastchanging and ever more open legal environment, senior judges are now increasingly involved in judicial dialogues across national divides. This polite exchange of information leads to mutual inspiration and 'cross-fertilization' on a variety of subjects, ${ }^{102}$ and this may be happening with drug policy as state drug laws are now commonly challenged on constitutional grounds. Normative questions as to the validity of the criminalisation of drug use are also becoming more prominent as the international human rights regime and the international drug control system are now recognized to be on a collision course. ${ }^{103}$ In order to settle these tricky legal questions and to balance law enforcement and respect for privacy, judges can use comparative law to inject 'outsider' insights into their reasoning to serve a 'subversive' purpose,${ }^{104}$ feeding judicial activism and circumventing legal conservatism. In that respect, a string of recent decisions by various supreme courts from all around the world may well pave the way for a transnational judicial understanding of drug 'personal consumption' as an activity that pertains to the constitutionally protected realm of the private. ${ }^{105}$

\section{CONCLUSION}

The limits of legal transfers in the engineering of social and economic changes on a global scale have been highlighted in the law and development literature. ${ }^{106}$ The failure of the international governance of drug policy provides another illustration of how a worldwide transplantation can go wrong, this time in the field of transnational criminal law. As the global order on drugs is now under extreme strain, with some countries establishing recreational markets for products banned under international law, and others pursuing a ruthless war against drug users, ${ }^{107}$ comparative law provides an ideal platform to describe the changing landscape for drug policy. Much can be learned from the diversity of national legal frameworks, both on the possibility and the danger of transferring criminal norms worldwide, and on the best and worst practices in implementing or circumventing international norms. Comparative law expands the agenda of "thinkable" possibilities. But it is unclear how much of this comparative knowledge can be of direct use for the policy maker. Indeed, there may be much to learn from elsewhere but not so much to transfer. While comparative analysis can certainly provide substantial contributions

\footnotetext{
${ }^{102}$ M. Andenas, D. Fairgrieve, 'Introduction: Finding a Common Language for Open Legal Systems', in Comparative Law before the Courts, eds. G. Canivet, M. Andenas, D. Fairgrieve (2004) xxvii.

${ }^{103}$ On this question, see R. Lines, Drug Control and Human Rights in International Law (2017), and D. Barrett and M. Nowak's seminal article, 'The United Nations and Drug Policy: Towards a Human Rights-Based Approach' in The Diversity of International Law: Essays in Honour of Professor Calliope K. Kpufa, eds. A Constantinides and N. Zaikai (2009) 468.

${ }^{104}$ G. Fletcher, 'Comparative Law as a Subversive Discipline' (1998) 46 American J. of Comparative Law 683

${ }^{105}$ A. Marks, 'Defining 'Personal Consumption' in Drug Legislation and Spanish Cannabis Clubs', International \& Comparative Law Quarterly 68 (2019), esp. Sec. VIII.

106 J. Gillepsie \& P. Nicholson (eds.), Law and Development and the Global Discourses of Legal Transfer (2012).

${ }^{107}$ For a general view, see A. Klein \& B. Stothard (eds.), Collapse of the Global Order on Drugs: From Ungass 2016 to Review 2019 (2018).
} 
to legal and policy knowledge, its ability to provide universal solutions applicable on a transnational basis should not be overrated. Even when grounded in sophisticated design, legal comparisons are always open to interpretation and can sometimes prove erroneous. ${ }^{108}$ In this respect, comparison of laws and regulatory measures on drugs is no substitute for a rigorous policy evaluation ${ }^{109}$ and a normative reflection on policy objectives and metrics of success. ${ }^{110}$

\footnotetext{
${ }^{108}$ For an example, see A. Stevens, 'Is policy "liberalization" associated with higher odds of adolescent cannabis use? A re-analysis of data from 38 countries' (2019) 66 International J. of Drug Policy 94. 109 EMCDDA, Evaluating Drug Policy: A Seven-step Guide to Support the Commissioning and Managing of Evaluations (2017).

${ }^{110}$ International Centre for Science in Drug Policy, 'A Call for a Reprioritization of Metrics to Evaluate Illicit Drug Policy' (2016) at https://www.unodc.org/documents/ungass2016/ Contributions/Civil/ICSDP/ICSDP_Open_Letter_EN_Web.pdf
} 